\title{
KOHESIVITAS SUAMI ISTRI DI USIA MADYA
}

\author{
Diah Anindita \& Khoiruddin Bashori \\ Fakultas Psikologi \\ Universitas Ahmad Dahlan \\ Jalan Kapas No. 9 Yogyakarta \\ bkhoiruddin@yahoo.com
}

\begin{abstract}
In the middle age, adjustment to developmental tasks will affect marital relationship. This study aimed to determine the cohesiveness of husband and wife who have entered middle adulthood, covering aspects of solidarity, marital satisfaction, interest, and affiliates and also the factors that affect the cohesiveness of husband and wife when the marriage age of 20 years or more. Subjects are three pairs of husband and wife who are legally married for over 20 years and each individual's age between $40-60$ years old. This qualitative research used the case study approach and collected data by semi-structured interviews and nonparticipant observation. The results showed that the cohesiveness of husband and wife owned in middle age is different in each pair. In the first couple showed low cohesion, high on the second couple, and medium for the third couple. In the third couple, there is a change before the peak of the conflict in mid-2011 by now. Factors that affect the cohesiveness of husband and wife in middle age is a social perception, social support, emotional regulation, a period of quiet in the middle ages, the intensity of togetherness, understanding of gender, temperament, and love.
\end{abstract}

Key words: Cohesiveness, Husband, Middle Age, Wife.

\begin{abstract}
Abstrak
Dalam usia madya, penyesuaian terhadap tugas-tugas perkembangan akan mempengaruhi hubungan suami istri. Penelitian ini bertujuan untuk mengetahui dan mempelajari kohesivitas suami istri pada pasangan yang telah memasuki usia dewasa madya, meliputi aspek solidaritas, kepuasan pernikahan, ketertarikan, dan afiliasi serta faktor yang mempengaruhi
\end{abstract}


kohesivitas suami istri tersebut ketika usia pernikahan 20 tahun atau lebih. Subjek penelitian adalah tiga pasang suami istri yang terikat perkawinan yang sah selama lebih dari 20 tahun dan usia masing-masing individu 4060 tahun. Metode penelitian yang digunakan adalah penelitian kualitatif dengan pendekatan studi kasus. Teknik pengumpulan data dilakukan dengan cara wawancara semi terstruktur dan observasi nonpartisipan. Hasil penelitian menunjukkan bahwa kohesivitas yang dimiliki suami istri di usia madya berbeda pada masing-masing pasangan. Pada pasangan pertama menunjukkan kohesivitas yang rendah, pada pasangan kedua tinggi, dan pada pasangan ketiga sedang. Pada pasangan ketiga, terjadi perubahan dari sebelum puncak konflik pada pertengahan 2011 dengan sekarang. Faktor-faktor yang mempengaruhi kohesivitas suami istri di usia madya adalah persepsi sosial, dukungan sosial, regulasi emosi, masa sepi di usia madya, intensitas kebersamaan, pemahaman gender, temperamen, dan cinta.

Kata kunci : Istri, Kohesivitas, Suami, Usia Madya.

\section{Pendahuluan}

Setiap orang yang memasuki gerbang kehidupan berkeluarga melalui perkawinan, tentu menginginkan terciptanya suatu keluarga yang bahagia lahir dan batin. Hal ini sesuai dengan tujuan perkawinan yang terdapat dalam undang-undang No. 1 tahun 1974 pasal 1 yang menyebutkan bahwa perkawinan ialah ikatan lahir batin antara seorang pria dengan seorang wanita sebagai suami istri dengan tujuan membentuk keluarga (rumah tangga) yang bahagia dan kekal berdasarkan Ketuhanan Yang Maha Esa.

Sekalipun dasar-dasar dan tujuan perkawinan telah disebutkan begitu mulia, namun saat ini banyak sekali rumah tangga yang tidak dapat meraih tujuan dari perkawinan itu. Perceraian dapat dialami oleh semua usia pasangan suami istri, baik pasangan muda yang baru menikah maupun pasangan suami istri yang memasuki usia dewasa madya yang sudah menikah lebih dari 20 tahun.

Berdasarkan data dari Pengadilan Agama Kota Yogyakarta tercatat pada tahun 2011 ada 500 kasus perceraian dan lebih dari 40 kasus perceraian itu terjadi pada pasangan yang telah menikah 20 tahun dan termasuk kelompok usia madya. Hal ini tidak akan terjadi bila masing-masing pasangan menyadari bahwa pada usia dewasa 
madya tersebut merupakan masa yang istimewa karena merupakan jembatan dari masa dewasa awal ke lansia. Di samping itu, mereka seharusnya juga dapat menyesuaikan diri terhadap perubahan jasmani dan mental yang dapat mempengaruhi hubungan dengan pasangannya. Semestinya pernikahan yang sudah bertahan lama memiliki kemungkinan kecil untuk perceraian dibandingkan dengan pernikahan yang baru saja terjadi, karena sebagai pasangan yang sudah lama hidup bersama, mereka membangun modal pernikahan ( marital capital) yaitu manfaat finansial dan emosional yang dibangun selama masa pernikahan yang lama, di mana cenderung membuat pasangan bertahan bersama-sama. Dengan adanya penyesuaian diri terhadap pasangannya, maka pasangan dapat menjaga kohesivitas pernikahannya.

Didik (2010) menyebutkan, kohesivitas sebagai kekuatan yang dapat menyatukan antarmanusia dalam suatu penyatuan. Shin dan Park (2011) dalam penelitiannya menyatakan, kohesivitas adalah salah satu hal yang penting dalam suatu kelompok atau hubungan interpersonal. Ramdhani dan Martono (1996) menyebutkan bahwa peningkatan kohesivitas dalam masyarakat dapat mendorong anggota kelompok untuk sama rasa dan sama-sama meningkatkan kemajuan kelompoknya.

Berdasarkan observasi yang telah peneliti lakukan, terdapat pasangan suami istri yang menunjukkan adanya kohesivitas yang rendah dengan seringnya terjadi perselisihan pendapat atau ketidakcocokan yang mengakibatkan pertengkaran. Hal ini sudah menjadi aktivitas rutin yang biasa mereka lakukan dan tidak dianggap tabu lagi. Bahkan, dengan suara yang keras yang dapat didengar oleh tetangga di sekitarnya.

Bany dan Johnson (dalam Setyobroto, 2003) menyebutkan beberapa determinan yang terkait dengan cohesiveness yaitu timbulnya solidaritas kelompok, kepuasan, attractiveness atau situasi yang menarik dalam kelompok, dan affiliation atau hubungan antar anggota kelompok tersebut.

Setyobroto (2003) menguraikan solidaritas kelompok adalah adanya kesatuan pemikiran dan perasaan, adanya agreement atau persetujuan dalam keinginan, pendapat, minat dan perasaan. Solidaritas yang kuat terjadi pada kelompok yang menunjukkan kekompakan hubungan atau cohesiveness dalam kelompok.

Kepuasan atau satisfaction memberikan kontribusi timbulnya kekompakan, karena kepuasan itu akan mendorong anggota untuk mendukung kegiatan operasional dan tercapainya tujuan.

Chaplin (2006) mengartikan attractiveness sebagai sesuatu yang memiliki kualitas-kualitas yang bisa mendatangkan tingkah laku yang menyebabkan kecenderungan mendekati sumber perangsang. 
Arronson dkk (2005) menyatakan bahwa salah satu determinan dari ketertarikan atau attractiveness adalah daya tarik. Ditemukan bahwa semakin kita melihat dan berinteraksi dengan orang, semakin besar kemungkinan mereka untuk menjadi teman kita atau kekasih. Festinger. dkk (dalam Baumeister dan Bushman 2008) menunjukkan bahwa daya tarik dan keakraban tidak hanya mengandalkan pada jarak fisik yang sebenarnya, tetapi juga pada jarak fungsional.

Baumeister dan Bushman, (2008) menyatakan bahwa ketertarikan mengacu pada apapun yang menarik dua orang atau lebih bersama-sama, membuat mereka ingin bersama-sama dan mungkin untuk membentuk hubungan akrab yang abadi. Dalam psikologi sosial, ini khusus digunakan untuk mengacu pada hal yang membuat orang-orang seperti atau mulai untuk mencintai satu sama lain.

Ketertarikan dapat juga berupa ketertarikan fisik atau physically attractive. Orang akan lebih menyukai orang lain yang enak untuk dilihat atau good looking. Good looking tidak hanya merujuk pada kecantikan atau ketampanan fisik, tetapi juga dari tingkah laku yang baik. Saat berkencan, orang yang romantis dapat menjadi orang yang menarik secara fisik (Arronson, dkk. 2005)

Setyobroto (2003) mengartikan afiliasi sebagai suatu asumsi pokok dalam teori pendidikan yang berhubungan dengan kohesivitas atau kekompakan suatu kelompok yaitu:

1. Kekompakan kelompok tergantung adanya saling menyukai antar anggota kelompok

2. Rasa kesatuan dan rasa memiliki.

Baron dan Byrne (2004) menyatakan bahwa kebutuhan untuk membina hubungan dengan orang lain (afiliasi) dalah motif dasar untuk mencari dan mempertahankan hubungan interpersonal. Kebutuhan afiliasi terkait dengan kecenderungan untuk membentuk pertemanan dan untuk bersosialisasi, untuk berinteraksi secara dekat dengan orang lain, untuk bekerjasama dan berkomunikasi dengan orang lain, dan untuk jatuh cinta.

Dengan terpenuhinya semua hal yang merupakan determinan yang berhubungan dengan kohesivitas, maka kesuksesan dan tujuan dari suatu kelompok akan tercapai (Setyobroto, 2003). Wicaksono dan Prabowo (2010) menyatakan terdapat beberapa faktor yang menyebabkan munculnya kohesivitas yaitu latar belakang yang sama atau kedekatan personal sebagai hal yang dapat menimbulkan ketertarikan terhadap orang lain. Selain itu sedikitnya anggota kelompok membuat anggota saling mengenal lebih dalam. Kebersamaan atau seringnya anggota kelompok melakukan kegiatan bersama dapat meningkatkan kohesivitas kelompok. 


\section{Metode Penelitian}

Penelitian ini adalah penelitian kualitatif yang menggunakan pendekatan studi kasus. Pendekatan studi kasus adalah fenomena khusus yang hadir dalam suatu konteks yang terbatasi (bounded context) (Poerwandari, 2009). Punch (dalam Poerwandari, 2009) mengatakan kasus dapat pula berupa keputusan, kebijakan, proses atau suatu peristiwa khusus tertentu. Penelitian ini mengambil responden tiga pasangan suami istri dari kelas sosial ekonomi bawah yang terikat perkawinan yang sah dengan usia 40 sampai 60 tahun dan telah menjalani perkawinan selama lebih dari 20 tahun. Kriteria ini ditentukan sesuai dengan tujuan penelitian. Hurlock (2004) menyebutkan bahwa usia madya membentang dari usia 40 sampai 60 tahun. Usia madya dipilih karena di masa ini, seseorang akan mengalami perubahan baik fisik maupun mental yang dapat mempengaruhi hubungan suami istri. Kriteria usia perkawinan 20 tahun didasarkan atas pertimbangan bahwa usia perkawinan yang lama telah mengalami banyak pengalaman dalam rumah tangga dan pasangan tersebut dapat bertahan dan menghadapi masalah yang dialami.

Metode pengumpulan data yang dilakukan adalah dengan metode wawancara dan observasi. Setelah peneliti memperoleh data dari teknik wawancara, maka data tersebut akan dianalisis dengan menggunakan teknik analisis tema (thematic analysis). Bentuk wawancara yang digunakan dalam penelitian ini adalah wawancara semi terstruktur, yaitu wawancara dengan pedoman umum. Dalam proses wawancara ini, peneliti dilengkapi pedoman wawancara yang umum tanpa bentuk pertanyaan yang konkrit (Poerwandari, 2009). Metode observasi yang dilakukan bersamaan dengan metode wawancara, karena kedua metode tersebut saling mendukung dalam mendapatkan data yang relevan. Observasi atau pengamatan dilakukan karena teknik pengamatan ini berdasarkan pengalaman secara langsung, teknik pengamatan juga memungkinkan melihat dan mengamati sendiri, kemudian mencatat perilaku dan kejadian sebagaimana yang terjadi pada keadaan yang sebenarnya (Guba dan Lincoln dalam Moleong, 2010). Pengamatan juga memungkinkan peneliti mencatat peristiwa yang berkaitan langsung dengan pengetahuan proporsional atau pengetahuan data serta memahami situasi-situasi rumit.

Marshall dan Rosman (Poerwandari, 2009), menyatakan untuk meningkatkan kredibilitas penelitian kualitatif, dapat dilakukan dengan metode triangulasi. Triangulasi yang digunakan dalam penelitian ini adalah triangulasi data, yaitu triangulasi yang mengacu pada upaya mengambil sumber data yang berbeda, dengan cara berbeda 
untuk memperoleh kejelasan mengenai suatu hal. Data dari berbagai sumber berbeda dapat digunakan untuk mengelaborasi dan memperkaya penelitian, dan dengan memperoleh data dari sumber berbeda, dengan teknik pengumpulan yang berbeda.

\section{Hasil dan Pembahasan}

Johnson and Johnson dalam Ramdhani dan Martono (1996) menyebutkan bahwa kohesivitas adalah suatu keadaan kelompok yang sudah membentuk kohesi, yang ditandai dengan adanya ketertarikan, ketergantungan, kerjasama yang kompak, dan kapasitas kelompok itu untuk mempertahankan keanggotaan para anggotanya sehingga akan bekerja sama dengan kompak dalam mencapai tujuan bersama. Satu kelompok dinamakan kohesif apabila terdiri dari anggota-anggota yang berusaha mengaktualisasikan berbagai kemampuan untuk mencapai kehendak bersama. Dalam kelompok yang sudah berkohesi, kepentingan individu sudah tidak diutamakan lagi. Bany dan Johnson dalam Setyobroto (2003) menyebutkan beberapa determinan yang terkait dengan cohesiveness yaitu antara lain timbulnya solidaritas kelompok, kepuasan, attractiveness atau situasi yang menarik dalam kelompok, dan affiliation atau hubungan antaranggota kelompok tersebut.

1. Solidaritas

Pada pasangan pertama solidaritas antara suami istri tidak terlalu baik. Hal ini dapat dilihat dari ketidaksamaan dalam cara mendidik anak yang sering memicu timbulnya pertengkaran. Suami sebagai pihak yang sering mengalah karena memahami karakter istri. Akan tetapi, untuk solidaritas dalam hal kesediaan pasangan untuk saling membantu cukup baik. Suami membantu mengerjakan pekerjaan rumah pada saat istri sakit dan istri membantu perekonomian dengan berjualan kecil-kecilan.

Pada pasangan kedua, solidaritas suami istri baik. Hal ini ditandai dengan kesamaan perasaan, pikiran, dan tujuan pernikahan sejak awal menikah. Tidak ada permasalahan sekecil apapun yang tidak dapat diselesaikan berdua karena suami istri berusaha menyatukan pikiran melalui musyawarah, termasuk dalam hal mendidik anak. Selain itu, terdapat kesepakatan bahwa tugas suami adalah mencari nafkah dan istri mengurus rumah. Suami istri dapat menerima dan menjalankan tugasnya dengan baik. Ketika istri membutuhkan bantuan, suami dengan sigap membantu istri.

Pada pasangan ketiga, solidaritas yang dimiliki suami istri tidak cukup baik. Untuk membantu ekonomi keluarga, sebagian besar waktu istri dihabiskan 
di luar rumah dengan bekerja. Akan tetapi, hal ini justru menjadi akar dari permasalahan antara suami istri. Suami merasa tidak diperhatikan dan rumah terbengkalai. Selain itu, istri sering merasa paling benar dan tidak mau menerima pendapat atau nasihat suami. Ketidakselarasan perasaan, pikiran, dan pandangan ini yang menyebabkan kurangnya solidaritas antara suami istri. Untuk perihal pekerjaan rumah tangga, suami lebih banyak mengerjakan pekerjaan istri ketika istri tidak di rumah seperti menjemur dan memasak.

\section{Kepuasan Pernikahan}

Chappel dan Leigh dalam Pujiastuti dan Retnowati (2004) menyebutkan bahwa kepuasan pernikahan sebagai evaluasi subjektif terhadap kualitas pernikahan secara keseluruhan. Apabila seseorang merasa puas terhadap pernikahan yang dijalani, maka ia beranggapan bahwa harapan, keinginan, dan tujuan yang ingin dicapai pada saat ia menikah telah terpenuhi, baik sebagian maupun seluruhnya.

Kepuasan pernikahan pada pasangan pertama tidak begitu tinggi. Hal ini ditandai dengan munculnya perasaan kecewa suami terhadap perubahan sikap istri dari sebelum menikah dengan sekarang. Suami mengharapkan sikap istri untuk dapat menjadi ibu rumah tangga yang baik dan dapat mendidik anak dengan baik bukan dengan cara kekerasan. Harapan suami ini ternyata tidak terpenuhi. Istri juga merasakan kekecewaan terhadap perubahan sifat suami yang menjadi pemarah. Istri juga tidak merasa puas terhadap kehidupan ekonomi karena sering kekurangan dan tidak dapat memenuhi kebutuhan anak.

Pada pasangan kedua, kepuasan pernikahan cukup tinggi. Hal ini ditandai dengan adanya kesesuaian harapan awal menikah dengan kondisi saat ini. Tujuan awal menikah juga tercapai, yaitu suami dapat berhenti dari perilaku maladaptif.

Pada pasangan ketiga, kepuasan pernikahan kurang dirasakan oleh suami istri. Terdapat pengalaman yang tidak membahagiakan selama pernikahan. Suami merasa tidak puas terhadap kesediaan waktu istri di rumah dan reaksi yang negatif ketika suami memberi nasihat. Walaupun terdapat ketidaksesuaian harapan awal menikah dengan kenyataan sekarang, dalam masalah ekonomi, istri dapat menerima perubahan keadaan ekonomi keluarga.

3. Ketertarikan

Pada pasangan pertama, ketertarikan antara suami istri bermula dari kedekatan fisik di SMA. Ketertarikan ini muncul karena sifat-sifat positif yang dimiliki oleh calon pasangan. Saat ini suami istri tidak lagi merasakan ketertarikan 
satu sama lain. Suami melihat perubahan fisik istri yang menjadi gemuk dan perubahan perilaku istri yang tidak lagi pendiam. Istri juga tidak menyukai perubahan suami yang menjadi mudah marah.

Pada pasangan kedua, ketertarikan berawal dari intensitas bertemu di tempat kerja. Ketertarikan ini muncul karena suami dan istri memandang calon pendamping mereka adalah sosok yang tepat. Istri merasa suami adalah seorang laki-laki yang penyayang dan suami melihat istri adalah seorang gadis perawan yang bisa merubah perilaku maladaptif suami. Sampai saat ini ketertarikan ini masih kuat dirasakan suami dan istri. Tidak ada perubahan di dalam diri suami maupun istri.

Pada pasangan ketiga, ketertarikan berawal dari pertemuan sebagai tetangga dekat. Istri tertarik karena status suami yang sudah bekerja. Suami tertarik terhadap sifat istri sebagai pekerja keras. Saat ini masih dirasakan ketertarikan antara suami istri pada pada pasangan ketiga ini.

4. Afiliasi

Dion (1973) menuliskan penelitiannya bahwa dalam kelompok yang kohesif, komunikasi dapat lebih lancar, kooperatif, dan lebih dimungkinkan memberi koreksi dan masukan yang positif. Yalom (Ramdhani dan Martono, 1996) menyatakan bahwa dalam kelompok yang kohesif akan ada saling keterbukaan. Hal ini dapat memunculkan perasaan berkelompok merupakan suatu kebutuhan. Kebutuhan ini demikian besar sehingga di dalamnya ada kekuatan ikatan antara satu dengan yang lainnya. Kekuatan ikatan ini membawa masing-masing anggota kepada saling pengertian, saling menghormati, dan berusaha untuk memenuhi harapan-harapan kelompok.

Pada pasangan pertama, afiliasi yang dimiliki adalah kurang. Hal ini ditandai dengan kurangnya minat untuk bersama pasangan serta tidak adanya rasa saling ketergantungan. Pada pasangan kedua, afiliasi yang dimiliki adalah baik. Ada perasaan untuk menjalin kebersamaan dan adanya keterbukaan terhadap pasangan. Pada pasangan ketiga, afiliasi yang dimiliki saat ini adalah cukup baik. Setelah konflik utama selesai, ada perasaan ketergantungan antara suami dan istri, walaupun minimnya intensitas kebersamaan.

Wicaksono dan Prabowo (2010) menyatakan terdapat faktor-faktor yang menyebabkan munculnya kohesivitas yaitu pengenalan mendalam terhadap orang lain dalam kelompok dan intensitas kebersamaan. Berdasarkan hasil penelitian, didapatkan faktor-faktor yang mempengaruhi kohesivitas suami istri di usia madya, yaitu: 
1. Pengenalan mendalam(Persepsi Sosial)

Latar belakang masing-masing individu termasuk kedekatan personal sebagai hal yang dapat menimbulkan ketertarikan terhadap orang lain. Selain itu, sedikitnya anggota kelompok membuat anggota saling mengenal lebih dalam. Di dalam psikologi hal ini dikenal sebagai persepsi sosial. Baron dan Byrne (2004) menjelaskan bahwa persepsi sosial adalah proses yang digunakan seseorang untuk mengetahui dan memahami orang lain. Terdapat empat aspek dalam persepsi sosial, yaitu komunikasi nonverbal, atribusi, pembentukan kesan dan manajemen kesan. Komunikasi non verbal adalah komunikasi antarindividu tanpa melibatkan isi bahasa lisan, namun mengandalkan bahasa-bahasa nonlisan melalui ekspresi wajah, kontak mata, dan bahasa tubuh. Dalam hubungan interpersonal, komunikasi nonverbal digunakan untuk memahami perasaan orang lain. Atribusi adalah proses untuk mengidentifikasi penyebab perilaku orang lain dan untuk kemudian mengerti tentang sifat-sifat yang menetap. Pembentukan kesan adalah proses menyusun atau membentuk kesan tentang orang lain. Manajemen kesan (presentasi diri) adalah usaha seseorang untuk menampilkan kesan pertama yang disukai pada orang lain.

Pada pasangan pertama, suami berusaha memahami karakter dan perasaan istri. Ekspresi emosi marah istri ditunjukkan dengan cara diam atau dengan nada suara tinggi. Suami berusaha mendekati istri ketika dirasa ada masalah. Apabila istri merasa terganggu atau tidak suka, suami akan diminta untuk pergi dari rumah dan suami mengikuti permintaan istrinya. Saat dirasa waktu yang diberikan suami kepada istri untuk menenangkan diri sudah cukup, suami akan kembali ke rumah dan tidak mengungkit masalah yang sebelumnya terjadi. Akan tetapi, bila suatu waktu ketika suami sedang lelah dan istri membahas masalah keuangan, suami dapat mengekspresikan emosinya dengan meninggikan suara. Istri tidak bisa memahami keadaan suami, sehingga pertengkaran tak dapat dicegah.

Berbeda dengan pasangan kedua. Suami memahami perasaan istrinya saat istri mengalami masalah. Diamnya istri akan menarik suami untuk menanyakan masalah yang terjadi dan pada akhirnya suami istri ini menyelesaikannya di luar rumah dengan cara bermusyawarah, misalnya di tempat makan.

Pada pasangan ketiga, terjadi perubahan sikap suami menjadi mudah marah ketika hatinya terluka karena ditinggal anak perempuan dan cucunya. Begitu juga dengan istri yang langsung mengekspresikan kemarahannya kepada 
suami ketika merasa dibohongi mengenai surat pengantar gugatan cerai. Ketidakmampuan kedua pihak untuk memahami keadaan pasangannya menjadi masalah yang dapat mengganggu hubungan suami istri.

\section{Intensitas Kebersamaan}

Kebersamaan atau seringnya anggota kelompok melakukan kegiatan bersama dapat meningkatkan kohesivitas kelompok. Suami istri yang memiliki quality time untuk bersama baik berdua maupun bersama anak akan menimbulkan perasaan ingin selalu bersama. Selain itu juga, tingginya intensitas bersama akan meningkatkan kohesivitas (Wicaksono dan Prabowo, 2010).

Intesitas kebersamaan yang tinggi terdapat pada pasangan kedua. Ada waktu yang diisi dengan kegiatan bersama seperti menonton TV dan bercengkrama bersama anak. Suami dan istri juga sering pergi berdua baik untuk menyelesaikan masalah keluarga ataupun sekedar menghabiskan waktu bersama. Kondisi berbeda terjadi pada pasangan pertama. Keluarga pada pasangan ini tidak terlalu sering berkumpul. Suami dan istri juga jarang pergi berdua. Sesekali mereka pergi untuk mengantarkan istri berobat dan membeli kebutuhan rumah. Intensitas bersama yang paling kecil terjadi pada pasangan ketiga. Di waktu pagi sampai sore hari, suami dan istri menghabiskan waktu bekerja di luar rumah. Ketika pulang ke rumah, suami istri sudah merasakan kelelahan karena kedua pekerjaan yang dilakukan mereka menguras tenaga mereka. Pekerjaan suami adalah juru parkir di rumah sakit, sedangkan istrinya adalah pengasuh anak di rumah tangga lain. Mereka tidak ada waktu lagi untuk berkumpul bersama anak mereka sendiri, apalagi untuk mereka berdua.

3. Cinta

Dampak dari tingginya intensitas bersama dan ketertarikan antar individu adalah timbulnya cinta. May (dalam Feist dan Feist, 2008) mendefinisikan cinta sebagai kesenangan terhadap kehadiran orang lain dan penegasan terhadap nilai dan perkembangan mereka sama seperti terhadap dirinya sendiri. Santrock (dalam Desmita 2007), menyebutkan bahwa cinta dapat diklasifikasikan menjadi empat bentuk, yaitu: altruisme, persahabatan, cinta yang romantis, dan cinta yang penuh perasaan atau persahabatan.

Pada pasangan pertama, cinta antara suami dan istri tidak kuat. Hal ini ditandai dengan adanya perasaan senang istri ketika sedang tidak bersama suami karena perubahan sikap suami menjadi pribadi yang mudah marah. Suami juga merasakan perasaan yang biasa-biasa saja ketika meninggalkan istri di rumah. 
Perasaan ini muncul karena suami percaya sepenuhnya kepada istri. Tidak ada lagi ungkapan-ungkapan sayang kepada pasangan karena hubungan yang terjalin sudah serasa saudara, bukan lagi cinta romantis kepada pasangannya.

Pada pasangan kedua, cinta yang dimiliki oleh suami istri cukup kuat. Hal ini ditandai dengan perasaan rindu untuk bersama pasangan dan berusaha untuk selalu menjalin komunikasi kepada pasangan. Pasangan kedua ini juga selalu berusaha menyelesaikan masalah yang dapat mengganggu hubungan suami istri. Cinta pada pasangan ini adalah cinta romantis.

Pada pasangan ketiga, cinta yang ada antara suami istri mengalami perubahan sebelum puncak konflik dan setelah konflik selesai. Sebelum konflik selesai, pasangan ini memiliki hubungan yang kurang baik. Suami dan istri mengutamakan ego masing-masing dan mudah meluapkan emosi. Setelah konflik terbesar selesai, suami istri saling mencoba untuk memperbaiki diri dengan saling memperhatikan dan munculnya perasaan rindu saat tidak bersama serta berusaha menjalin komunikasi dengan pasangan.

\section{Dukungan sosial}

Sarason, dkk. (dalam Hartanti, 2002) mendefinisikan dukungan sosial sebagai suatu keadaan yang bermanfaat bagi individu yang diperoleh dari orang lain yang dapat dipercaya. Dari interaksi ini, individu menjadi tahu bahwa orang lain memperhatikan, menghargai, dan mencintai dirinya.

Ketiga pasangan suami istri mendapatkan dukungan sosial yang berbeda. Pasangan pertama mendapatkan dukungan sosial berupa nasihat dari anak dan dukungan finansial dari keluarga suami. Pada pasangan kedua dukungan sosial yang didapatkan berupa dukungan emosi dari anak. Pasangan ketiga mendapatkan dukungan sosial berupa dukungan emosi dan dukungan penilaian berupa persetujuan terhadap keputusan istri. Dukungan sosial seharusnya dapat membantu pasangan dalam menyelesaikan masalah. Akan tetapi, kesalahan persepsi terhadap dukungan dari orang lain dapat memperkeruh masalah. Hal ini terjadi pada pasangan ketiga. Ketika terjadi masalah dalam rumah tangga, istri mencari dukungan dari orangtuanya. Suami merasa bahwa keluarga istri memberikan persetujuan kepada istri untuk berpisah dengan suami.

5. Masa sepi di usia madya

Hurlock (2004) memaparkan berbagai karakteristik usia madya, salah satunya adalah terjadinya masa sepi di usia madya. Masa sepi ini dirasakan 
ketika anak-anak tidak lagi tinggal bersama orang tuanya, sehingga pasangan suami istri di usia madya merasakan kesepian dan kebosanan di dalam rumah.

Pada pasangan pertama perginya anak pertama laki-laki karena menikah tidak berpengaruh terhadap hubungan suami istri. Pada pasangan kedua hal ini tidak terjadi karena kedua anak masih tinggal bersama orang tua. Berbeda dengan pasangan ketiga, terjadi perubahan keadaan keluarga ketika anak pertama perempuan meninggalkan rumah karena sudah menikah. Suami istri mengalami puncak pertengkaran dan hampir berujung pada perceraian. Hal ini disebabkan suami menjadi mudah marah karena adanya rasa sepi ditinggalkan oleh anak pertama dan cucu satu-satunya. Selain itu, tidak ada lagi orang yang mengurus rumah yang biasanya dikerjakan oleh anak pertamanya. Hal ini menjadi masalah besar ketika istri bekerja dan banyak meninggalkan pekerjaan rumah tangganya.

6. Regulasi emosi

Regulasi emosi adalah kemampuan untuk tetap tenang di bawah tekanan. Individu yang memiliki kemampuan meregulasi emosi dapat mengendalikan dirinya apabila sedang kesal dan dapat mengatasi rasa cemas, sedih, atau marah sehingga mempercepat dalam pemecahan suatu masalah. Pengekspresian emosi, baik negatif maupun positif merupakan hal yang sehat dan konstruktif asalkan dilakukan dengan tepat. Pengekpresian emosi yang tepat merupakan salah satu kemampuan individu yang resilient. Dua hal penting yang terkait dengan regulasi emosi, yaitu ketenangan (calming) dan fokus (focusing). Individu yang mampu mengelola kedua keterampilan ini, dapat membantu meredakan emosi yang ada, memfokuskan pikiran-pikiran yang mengganggu dan mengurangi stres (Reivich dan Shatté, 2002).

Pada pasangan pertama, seringkali suami dan istri tidak dapat meregulasi emosi mereka dengan baik, sehingga memunculkan pertengkaran. Pada pasangan kedua, regulasi emosi dapat berjalan dengan baik. Suami dan istri bisa saling mengontrol emosi negatifnya sehingga menciptakan kerukunan. Pada pasangan ketiga, terdapat perubahan regulasi emosi sebelum konflik besar dengan setelah konflik besar teratasi. Sebelum konflik seringkali pasangan ketiga ini tidak dapat meregulasi emosi mereka dengan baik, sehingga menyebabkan terjadinya pertengkaran bahkan hal ini menjadi penyebab utama krisisnya pernikahan yang hampir berujung pada perceraian. Akan tetapi, setelah selesainya konflik antara suami istri, mereka mengubah regulasi emosi yang dilakukan adalah 
dengan diam untuk menghindari konflik karena peluapan emosi yang salah.

7. Gender: peran gender dalam pernikahan

Zammichieli, dkk. (dalam Baron dan Byrne, 2004) menyatakan, pernikahan yang paling bahagia adalah antara dua orang androgini. Androgini adalah kondisi yang di dalamnya terdapat beberapa ciri pria dan beberapa ciri wanita hadir bersamaan dalam satu individu yang sama (Reber dan Reber, 2010). Ciri perilaku yang dimaksud adalah pelekatan ciri tertentu yang dibedakan antara laki-laki dan perempuan yang terbentuk berdasarkan pandangan sosial masyarakat. Laki-laki dididentikkan dengan sosok yang kuat sehingga memiliki tugas sebagai kepala rumah tangga, penentu keputusan, dan sebagai pencari nafkah utama untuk menghidupi keluarga. Perempuan adalah sebagai istri yaitu seorang pendamping yang memiliki tugas mendampingi suami, mengurus rumah dan anak, serta menerima segala keputusan suami. Pandangan-pandangan tradisional ini dapat mempengaruhi kehidupan suami istri dalam pernikahan.

Pengaruh stereotip gender terhadap kohesivitas pernikahan sangat nampak terjadi pada pasangan ketiga. Suami merasa bahwa tugas istri adalah mengurus rumah. Akan tetapi, istri yang diharapkan dapat mengerjakan pekerjaan rumah justru sibuk mengurusi rumah orang lain sebagai tempat istri bekerja. Hal ini terjadi sebelum istri menyadari perannya sebagai istri. Saat ini istri merasa lebih sadar bahwa tugas utama wanita adalah sebagai istri dan ibu yang dapat menjaga keutuhan keluarga. Selain itu, agama memandang bahwa termasuk perbuatan berdosa jika seorang istri membantah suami.

\section{Temperamen}

Para peneliti setuju bahwa temperamen termasuk dalam perbedaan individu dalam hal emosi (Goldsmith, dkk. dalam Cole, dkk. 2004). Artinya, perbedaan individu dalam temperamen mencerminkan bias biologis terhadap pengalaman dan ekspresi tertentu. Sebuah pendekatan (Rothbart dan Bates, Rothbart dan Derryberry dalam Cole, dkk., 2004) menjelaskan ciri temperamen yang menjadi perbedaan individual adalah:

a. Reaktivitas, yaitu kecepatan dan intensitas aktifitas emosi awal. Reaktivitas untuk emosi negatif yang berbeda terjadi pada suami dan istri. Pada pasangan pertama, suami istri memiliki reaktivitas yang hampir sama. Akan tetapi, suami terkadang lebih bisa melakukan regulasi emosi. Pada pasangan kedua, sebenarnya terdapat perbedaan jauh antara suami dan istri. Suami memiliki reaktivitas yang tinggi. Akan tetapi, istri dapat memahami dan 
tidak pernah berperilaku yang dapat memicu reaktivitas emosi negatif suami. Pada pasangan ketiga, rekativitas yang sama terdapat pada suami dan istri. Akan tetapi, untuk menghindari konflik, reaktivitas yang tadinya spontan, saat ini menjadi reaksi diam.

b. Pengaturan diri, yaitu kemampuan untuk mengubah intensitas dan durasi dari emosi awal yang terungkap dari strategi perilaku, seperti keengganan menatap, menarik diri, atau mendekati seseorang. Pada pasangan pertama, pengaturan diri yang dilakukan oleh istri adalah keengganan menatap dan menarik diri. Pada pasangan kedua pengaturan diri yang dilakukan istri adalah menarik diri, sedangkan pada pasangan ketiga pengaturan diri yang dilakukan suami dan istri sama yaitu dengan menarik diri dan keengganan menatap atau bertegur sapa kepada pasangan.

Berdasarkan hasil wawancara dan observasi yang diperoleh, maka faktorfaktor yang mempengaruhi kohesivitas suami istri di usia madya dapat digambarkan seperti dalam skema berikut:

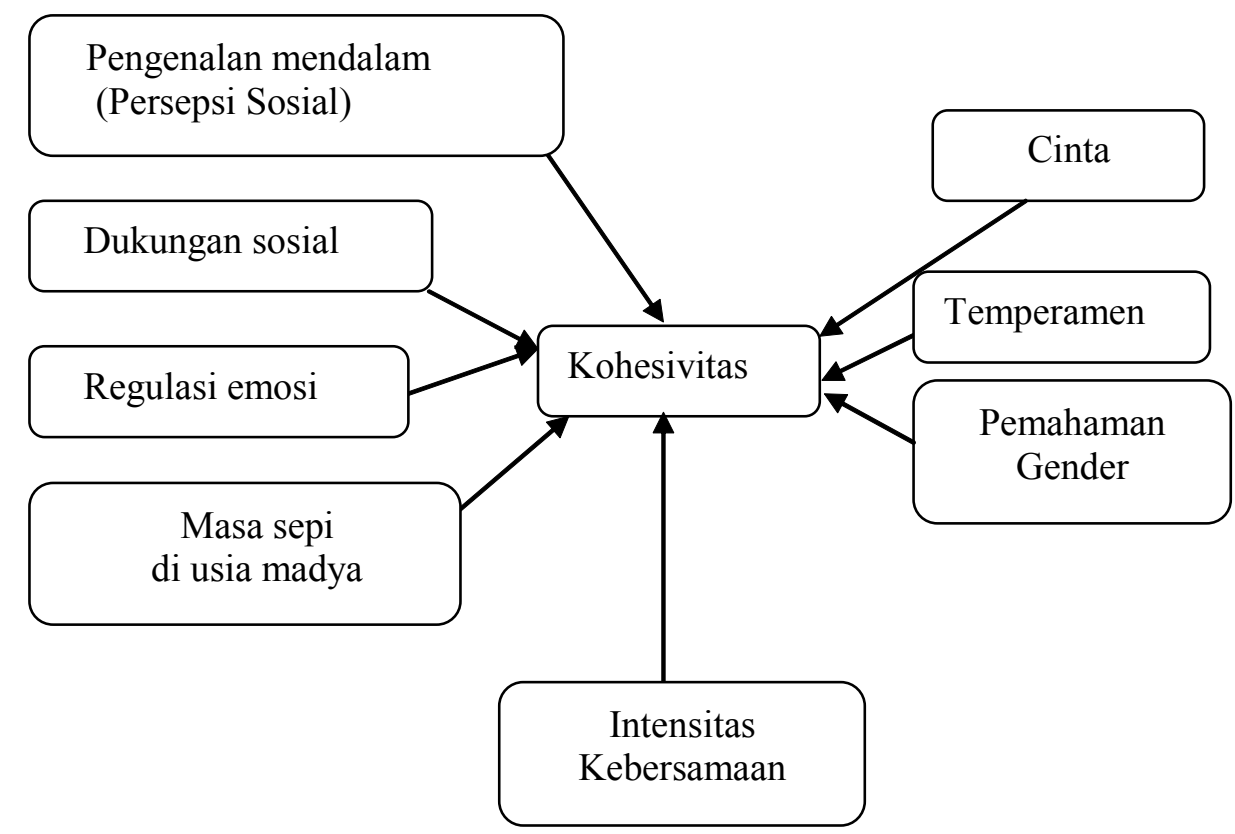

Skema 1. Faktor-Faktor yang mempengaruhi kohesivitas suami istri di usia madya

\section{Simpulan}

Kohesivitas suami istri dari kelas sosial ekonomi bawah pada usia madya dengan usia pernikahan 20 tahun dapat mengalami perubahan. Dari ketiga pasang subjek 
penelitian menunjukkan dinamika kohesivitas yang berbeda. Hal ini ditunjukkan dengan bukti pada keempat aspek kohesivitas yang dimaksud, yaitu: solidaritas, kepuasan pernikahan, ketertarikan, dan afiliasi.

Faktor-faktor yang mempengaruhi kohesivitas suami istri di usia madya dari kalangan kelas sosial ekonomi bawah adalah pengenalan mendalam, intensitas kebersamaan, cinta, dukungan sosial, masa sepi di usia madya, regulasi emosi, gender (peran gender dalam pernikahan), dan temperamen.

\section{Daftar Pustaka}

Arronson, E., Timothy D. W., Robin M. A. (2005). Fifth Edition Social Psychology. Pearson Education international: New Jersey.

Baumeister, R. F., Bushman, B. J.. (2008). Social Psychology and Human Nature. Thomson Wadsworth: USA.

Baron, R. A,. \& Byrne, D. (2004). Psikologi Sosial. Edisi Kesepuluh Jilid 1. Jakarta: Erlangga.

Chaplin, C. P. (2006). Kamus Lengkap Psikologi. Jakarta: P.T. Raja Grafindo.

Cole, P. M., Martin, S. E., dan Dennis, T. A. (2004). Emotion Regulation as a Scientific Construct: Methodological Challenges and Directions for Child Development Research. Journal Child Development. 75. 317 - 333.

Desmita. (2007). Psikologi Perkembangan. Bandung: Remaja Rosdakarya.

Didik. (2010). Prinsip Interaksi Sosial. http://didikcahsid.wordpress.com/2010/01/ 03/prinsip-resiprokasi-atau-timbal-balik.html. 15 Maret 2010.

Dion, K. (1973). Cohesiveness as a Determinant of in Group Out Group Bias. Journal of Personality and Social Psychology. 28: 163-171.

Feist, J. \& Feist, G. J. (2008). Theories of Personality. Edisi keenam. Yogyakarta: Pustaka Pelajar.

Hartanti. (2002). Peran Sense of Humor dan Dukungan Sosial pada Tingkat Depresi Penderita Dewasa Pascastroke. Anima, Indonesian Psychologycal Journal. 17 (2) : 107-119.

Hurlock, E. B. (2004). Psikologi Perkembangan, Edisi Kelima. Jakarta: Erlangga. Moleong, L. J. (2010). Metodologi Penelitian Kualitatif. Edisi Revisi. Bandung: 
PT. Remaja Rosdakarya.

Poerwandari, E. R. (2009). Pendekatan Kualitatif untuk Penelitian Perilaku Manusia. Banten: Perfecta LPSP3 Fakultas Psikologi Universitas Indonesia.

Pujiastuti, E., \& Retnowati, S. (2004). Kepuasan Pernikahan dengan Depresi pada Kelompok Wanita Menikah yang Bekerja dan yang Tidak Bekerja. Humanitas Indonesian Psychological Journal. 1: 1-9.

Ramdhani, N. dan Martono. (1996). Kohesivitas pada Masyarakat Miskin. Jurnal Psikologi. 2: 84-94.

Reber, A. S,. \& Reber, E. S. (2010). Kamus Psikologi. Yogyakarta: Pustaka Pelajar.

Reivich \& Shatté. (2002). The Resilience Factor: 7 Essential Skills for Overcoming Life's Inevitable Obstacles. New York City: Broadway Books.

Setyobroto, S. (2003). Psikologi Sosial Pendidikan. Jakarta: Penerbit Solo.

Shin, S.Y. \& Park, W. (2011). Moderating Effects of Group Cohesiveness in Competency Performance Relationships: A Multy-Level Study. Journal of Behavioral Studies in Business. Aabri: 1-15.

Wicaksono, B. \& Prabowo, H. (2010). Kohesivitas Tim Pendukung Sepakbola Persija. Jurnal Psikologi Gunadarma. 3 (2) 154-159. 